\title{
Residual behavior of abamectin and cyflufenamid in squash plants
}

\author{
Aly A. Aly Shalaby \\ Plant Protection Department, Faculty of Agriculture, Zagazig University - Egypt \\ Corresponding author:Shalabey3001@yahoo.com
}

\begin{abstract}
Squash plants were sprayed with Vertimec (abamectin) 1.8\% EC and Ritreap (cyflufenamid) 5\% EW at the rate of $40 \mathrm{~cm}^{3} / 100 \mathrm{~L}$ water and $20 \mathrm{~cm}^{3} / 100 \mathrm{~L}$ water, respectively during the summer season of 2016. Samples leaves, fruits and soil were collected at $2 \mathrm{hrs}$ to 12 days after application and QuEChERS method was used for extraction and clean-up and analyzed using HPLC and gas chromatography for abamectin and cyflufenamid, respectively. Results revealed that, the initial amounts of each pesticide in leaves were much higher than those in squash fruits. Loss percentages in residues were higher in squash fruits than leaves. The residues amounts of the two tested pesticides were more greatly detected in peel than that the pulp. Data also show that washing and peeling of squash fruits resulted in removing reasonable amounts of residues especially with the first three samples. The rate of dissipation in abamectin was more than in cyflufenamid and the consumable safety time was 6 days after application of these pesticides on Squash fruits.
\end{abstract}

Keywords: abamectin, cyflufenamid, QuEChERS, squash, residues

\section{Introduction}

In Egypt, squash fruit is important vegetables for human consumption in mature stages. Squash plants are liable to be infested with different insect pests and diseases which usually cause serious injury and reduction to the final yield. The extensive use of synthetic organic pesticides for this purpose has inevitably been followed by many problems. One of the most problems is a remaining residue in vegetables and fruits especially with highly stable and persistent insecticides. (AL-Eed, 2006). Food contamination with health hazardous materials (pesticides) is a target of investigations for scientists concerned with environmental pollutants. Pollution with these materials is a serious problem facing the world. However, its risk is increasing in the third world countries due to lack of regulations, lack of awareness among consumers, lack of research, and lack of efficient monitoring programs dealing with the incidence of these hazardous materials in food. (Saitta, et al., 2000 and Gonzalez, et al., 2003).

Abamectin is used to control insect and mite pests of a range of agronomic, fruit, vegetable and ornamental crops (MacBean, 2012). Cyflufenamidis used to control of Powdery mildew in wheat, top fruit, vegetables and powdery mildew in cereals (Haramoto et al., 2006).

The aim of this study was to investigate the dissipation rate of abamectin and cyflufenamid up on application in squash fruits under field conditions in addition the effect of peeling and washing squash fruits as home processing were also studied so as to provide basic information for developing regulation regarding the safe use of abamectin and cyflufenamid in pest management strategies and to protect the environment and public health.

\section{Material and Methods}

\section{I- Pesticide selected for this study:}

The pesticides used and their rates in gram active ingredients (a.i.) per feddan $\left(1\right.$ feddan $\left.=4.200 \mathrm{~m}^{2}\right)$ were abamectin, (Vertimec $1.8 \% \mathrm{EC}$ ) at $0.72 \mathrm{~g}$ and cyflufenamid, (Ritreap 5\% EW) at1 g. Rates of pesticideal application were chosen on the basis of recommended rates on other related crops.

\section{2- Field Experiment and sampling}

Field experiments were carried out in a private field of squash (Cucurbita pepo ver refera) located at El-Tahra village, Zagazig district, Sharkia governorate during the summer season of 2016. Mature plants were sprayed with Vertimec and Ritreap once at the rate of $40 \mathrm{~cm}^{3} / 100 \mathrm{~L}$ water, 20 $\mathrm{cm}^{3}$ / $100 \mathrm{~L}$ water, respectively the control plots were left unsprayed. A knapsack hand spray fitted with one nozzle boom was used. Samples of squash (leaves and fruits) and soil under treated plants were taken from three replicates for each treatment. Samples were taken 2 hrs after pesticide application to determine the initial deposits of each pesticide. Afterward, samples were collected randomly after 1,3,6,9, and 12 days after application. Fruit samples were divided into three subsamples, the first one was left unwashed, the second one was washed with tap water and left for air dryness and the third one was peeled.

\section{3- Residues determination}

Ten $g$ of the homogenized samples (washed fruits, unwashed fruits, peel, pulp and leaves) were transferred in a $50 \mathrm{ml}$ centrifuge tube. Fifteen milliliters of $1.0 \%$ acidified acetonitrile with acetic acid were added; the screw cap was closed and vigorously shaken for 1 min using a Vortex mixer at 
maximum speed. Afterwards, $4 \mathrm{~g}$ of anhydrous $\mathrm{MgSO}_{4}, 1 \mathrm{~g}$ of $\mathrm{NaCl}, 1 \mathrm{~g}$ sodium citrate Dehydrate were added, then extracted by shaking vigorously on Vortex for $2 \mathrm{~min}$ and centrifuged for $10 \mathrm{~min}$ at 5,000 rpm (Lehotayet al. 2010). Residues of abamectin and cyflufenamid were extracted from soil samples as follow: $50 \mathrm{~g}$ representative soil sample (crushed into a hummer mill then sieved to a granule size of $40-120$ mesh) was transferred to $500 \mathrm{ml}$ conical flask and extracted by shaking mechanically with $200 \mathrm{ml}$ acetone for cyflufenamid and $200 \mathrm{ml}$ ethyl acetate for abamectin for $30 \mathrm{~min}$. the extract was carefully decanted and filtered through a clean pad of cotton into 100 graduated cylinder. The extracts were evaporated with a vacuum rotary evaporator at $35^{\circ} \mathrm{C}$ on a water bath until dryness and kept to final determination step.

\section{4- Determination of pesticide residues}

Cyflufenamid was determined according to Hirahara et al. 2005 Agilent Technologies 7890A gas chromatograph equipped with Electron capture detector (ECD) under the following operation conditions: Column: DB-17 (15 $\mathrm{m} \times 0.32 \mathrm{~mm} \times 0.52 \mu \mathrm{m}$ film thickness). Column temperature: $220{ }^{\circ} \mathrm{C}$ for one minute heated to $270{ }^{\circ} \mathrm{C}$ at $10^{\circ} \mathrm{C} / \mathrm{min}$. Injector temperature: $300{ }^{\circ} \mathrm{C}$. Detector temperature: $320{ }^{\circ} \mathrm{C}$. Carrier gas: N2. Flow rate: $3.2 \mathrm{ml} / \mathrm{min}$. Abamectin was determined by HPLC with an Agilent 1260 HPLC system (USA), with quaternary pump, auto sampler injector, thermostat compartment for the column, and photodiode array detector. The chromatographic column was Zorbax C18 XDB $(250 \times 4.6 \mathrm{~mm}, 5 \mathrm{~mm})$. The column was kept at room temperature. Flow rate of mobile phase (acetonitrile/ water, 90:10, v/v) was 1 $\mathrm{ml} \mathrm{min}{ }^{-1}$, and injection volume was $20 \mu \mathrm{L}$.

Under these conditions the recovery percentages at $1 \mathrm{mg} / \mathrm{kg}$ level were 92, 89, 91, 90 and $88 \%$ in leaves, fruits, peel, pulp and soil, respectively for cyflufenamid. The corresponding values for abamectin were $93,87,90,86$ and $88 \%$.

\section{Results and discussion}

The results of cyflufenamid and abamectin residues in squash leaves, whole fruits, peel of squash fruits, pulp of squash fruits, washed fruits and soil are presented in Tables 1 and 2. The initial deposits ( $2 \mathrm{hrs}$ after spraying) of cyflufenamid in the leaves of squash and soil were found to be 3.694 and $0.653 \mathrm{mg} / \mathrm{kg}$ (Table, 1). Twelve days after application, cyflufenamid was decreased in the leaves and soils to 0.183 and $0.011 \mathrm{mg} / \mathrm{kg}$. The recorded percentage of dissipation at this period was 95.05 and $98.37 \%$, respectively. Likewise, the initial amount of cyflufenamid detected in the unwashed whole fruits was $2.104 \mathrm{mg} / \mathrm{kg}$ and gradually decreased to reach $0.05 \mathrm{mg} / \mathrm{kg}$ after 6 days of spraying.

Table 1. Residues of cyflufenamid detected in squash leaves, fruits and soil under treated plants

\begin{tabular}{|c|c|c|c|c|c|c|c|}
\hline \multirow{2}{*}{$\begin{array}{l}\text { Days after } \\
\text { treatment }\end{array}$} & \multirow{2}{*}{$\begin{array}{l}\text { leaves } \\
\text { residues } \\
(\mathrm{mg} / \mathrm{kg})\end{array}$} & \multicolumn{4}{|c|}{ Unwashed fruits } & \multirow{2}{*}{$\begin{array}{l}\text { washed } \\
\text { fruits } \\
\text { residues } \\
(\mathrm{mg} / \mathrm{kg} \text { ) }\end{array}$} & \multirow{2}{*}{$\begin{array}{l}\text { Soil residues } \\
(\mathrm{mg} / \mathrm{kg})\end{array}$} \\
\hline & & $\begin{array}{c}\text { peel } \\
\text { residues } \\
(\mathrm{mg} / \mathrm{kg})\end{array}$ & $\begin{array}{c}\text { pulp } \\
\text { residues } \\
\text { (mg/kg) }\end{array}$ & $\begin{array}{c}\text { Migration }^{* * *} \\
\%\end{array}$ & $\begin{array}{c}\text { fruits } \\
\text { residues } \\
(\mathrm{mg} / \mathrm{kg})\end{array}$ & & \\
\hline $\begin{array}{c}\text { Initial (2 } \\
\text { hrs) }\end{array}$ & 3.694 & 2.334 & $\begin{array}{l}\text { UND } \\
100^{*}\end{array}$ & 0.00 & 2.104 & $\begin{array}{l}1.911 \\
9.17^{* * *}\end{array}$ & 0.653 \\
\hline 1 & $\begin{array}{c}3.041 \\
(17.67) \\
\end{array}$ & $\begin{array}{r}1.080 \\
(53.73) \\
\end{array}$ & $\begin{array}{c}0.12 \\
88.88^{*}\end{array}$ & 5.14 & $\begin{array}{r}1.003 \\
(52.33) \\
\end{array}$ & $\begin{array}{l}0.980 \\
2.29^{* *}\end{array}$ & $\begin{array}{r}0.299 \\
(54.21) \\
\end{array}$ \\
\hline 3 & $\begin{array}{c}1.958 \\
(46.99)\end{array}$ & $\begin{array}{c}0.360 \\
(83.13)\end{array}$ & $\begin{array}{c}0.29 \\
19.44^{*}\end{array}$ & 12.42 & $\begin{array}{c}0.39 \\
(81.46)\end{array}$ & $\begin{array}{c}0.36 \\
0.07^{\text {*** }}\end{array}$ & $\begin{array}{c}0.154 \\
(76.42)\end{array}$ \\
\hline 6 & $\begin{array}{c}0.723 \\
(80.43)\end{array}$ & $\begin{array}{c}0.031 \\
(98.59)\end{array}$ & $\begin{array}{l}0.028 \\
9.68^{*}\end{array}$ & 1.2 & $\begin{array}{c}0.050 \\
(97.83)\end{array}$ & $\begin{array}{l}0.050 \\
0.00^{* *}\end{array}$ & $\begin{array}{c}0.108 \\
(83.46)\end{array}$ \\
\hline 9 & $\begin{array}{c}0.350 \\
(90.52)\end{array}$ & $\begin{array}{c}0.01 \\
(99.27)\end{array}$ & UND & & UND & UND & $\begin{array}{c}0.035 \\
(94.64)\end{array}$ \\
\hline 12 & $\begin{array}{c}0.183 \\
(95.05)\end{array}$ & UND & UND & & UND & UND & $\begin{array}{c}0.011 \\
(98.31)\end{array}$ \\
\hline $\mathrm{K}$ & 0.02654 & 1.2042 & & & 1.6097 & & 0.1645 \\
\hline$t_{1 / 2}$ & 2.612 & 0.545 & & & 0.431 & & 0.421 \\
\hline
\end{tabular}

*\% loss by peeling, ** \% loss by washing, Number between brackets indicate the \% loss, UND = undetectable amounts, $\mathrm{K}=$ degradation rate, $\mathrm{t}_{1 / 2}=$ half - life

$* * *$ Migration $\%=\frac{\text { Residual amounts in pulp at indicated days }}{\text { Initial deposits } \text { on peel }} \times 100$

Data in the same table clearly showed the effect of home processing like washing with tap water and peeling on the reduction of cyflufenamid residues in squash fruits. The data indicated that the removal percentages of cyflufenamid residues by peeling $100 \%$ (after 2 hrs and days, 9) and 88.88, 19.44 and
$9.68 \%$ after 1,3 and 6 days of spraying, respectively. The migration percentages in relation to the initial deposits on squash peel were $0.00 \%, 5.14 \%, 12.42 \%$ and $1.2 \%$ after 2 hrs, 1, 3 and 6 days, respectively. In addition, the removal percentages of cyflufenamid residues in squash fruits ranged between $0.00 \%$ and 
$9.17 \%$ by washing at the same time of the treatment. The result also showed that there were different between the peeling procedure and the washing; the peeling process decreased the residue amounts of cyflufenamid on squash fruits much more than washing.

On ground of the residues of abamectin (Table, 2), data show that abamectin degraded gradually in leaves and soil under treated plants until the end of the experimental period (12 days). The initial deposits of abamectin in leaves and soil, as determined two hours after spraying were 2.451 and $0.053 \mathrm{mg} / \mathrm{kg}$, respectively. Such amounts were decreased to 0.045 and $0.001 \mathrm{mg} / \mathrm{kg}$ through 12 days of spraying indicating $98.16 \%$ and $98.11 \%$ loss, respectively.

Table 2. Residues of abamectin detected in squash leaves, fruits and soil under treated plants

\begin{tabular}{|c|c|c|c|c|c|c|c|}
\hline \multirow{2}{*}{$\begin{array}{l}\text { Days after } \\
\text { treatment }\end{array}$} & \multirow{2}{*}{$\begin{array}{c}\text { leaves } \\
\text { residues } \\
(\mathrm{mg} / \mathrm{kg})\end{array}$} & \multicolumn{4}{|c|}{ Unwashed fruits } & \multirow{2}{*}{$\begin{array}{l}\text { washed } \\
\text { fruits } \\
\text { residues } \\
(\mathrm{mg} / \mathrm{kg})\end{array}$} & \multirow{2}{*}{$\begin{array}{c}\text { Soil residues } \\
(\mathrm{mg} / \mathrm{kg})\end{array}$} \\
\hline & & $\begin{array}{c}\text { Peel } \\
\text { residues } \\
(\mathrm{mg} / \mathrm{kg})\end{array}$ & $\begin{array}{c}\text { pulp } \\
\text { residues } \\
(\mathrm{mg} / \mathrm{kg})\end{array}$ & $\begin{array}{c}\text { Migration }^{* * *} \\
\%\end{array}$ & $\begin{array}{c}\text { fruits } \\
\text { residues } \\
(\mathrm{mg} / \mathrm{kg})\end{array}$ & & \\
\hline $\begin{array}{c}\text { Initial (2 } \\
\text { hrs) }\end{array}$ & 2.451 & 0.98 & $\begin{array}{l}\text { UND } \\
100^{*}\end{array}$ & 0.00 & 0.95 & $\begin{array}{c}0.81 \\
14.74^{* *}\end{array}$ & 0.053 \\
\hline 1 & $\begin{array}{c}1.843 \\
(24.81)\end{array}$ & $\begin{array}{c}0.69 \\
(29.59)\end{array}$ & $\begin{array}{c}0.07 \\
89.85^{*}\end{array}$ & 7.14 & $\begin{array}{c}0.53 \\
(44.21)\end{array}$ & $\begin{array}{c}0.48 \\
9.43^{* *}\end{array}$ & $\begin{array}{c}0.041 \\
(22.64)\end{array}$ \\
\hline 3 & $\begin{array}{c}0.985 \\
(59.81)\end{array}$ & $\begin{array}{c}0.24 \\
(61.22)\end{array}$ & $\begin{array}{c}0.14 \\
63.16^{*}\end{array}$ & 14.29 & $\begin{array}{c}0.172 \\
(81.89)\end{array}$ & $\begin{array}{l}0.160 \\
6.98^{* *}\end{array}$ & $\begin{array}{c}0.025 \\
(52.83)\end{array}$ \\
\hline 6 & $\begin{array}{c}0.340 \\
(86.13)\end{array}$ & $\begin{array}{c}0.072 \\
(92.65)\end{array}$ & $\begin{array}{l}0.035 \\
51.39^{*}\end{array}$ & 3.57 & $\begin{array}{c}0.039 \\
(95.89)\end{array}$ & $\begin{array}{l}0.037 \\
5.13^{* *}\end{array}$ & $\begin{array}{c}0.015 \\
(71.69)\end{array}$ \\
\hline 9 & $\begin{array}{c}0.142 \\
(94.21)\end{array}$ & $\begin{array}{c}0.033 \\
(96.63)\end{array}$ & UND & & UND & UND & $\begin{array}{c}0.003 \\
(94.34)\end{array}$ \\
\hline 12 & $\begin{array}{r}0.045 \\
(98.16) \\
\end{array}$ & UND & UND & & UND & UND & $\begin{array}{c}0.001 \\
(98.11) \\
\end{array}$ \\
\hline $\mathrm{K}$ & 1.60973 & 3.8383 & & & 1.8975 & & 3.2899 \\
\hline$t_{1 / 2}$ & 0.6478 & 0.1805 & & & 0.3652 & & 0.2106 \\
\hline
\end{tabular}

*\% loss by peeling, ** \% loss by washing, Number between brackets indicate the \% loss, UND = undetectable amounts, $\mathrm{K}=$ degradation rate, $\mathrm{t}_{1 / 2}=$ half - life

$* * *$ Migration $\%=\frac{\text { Residual amounts in pulp at indicated days }}{\text { Initial deposits on } p e e l}$

The picture differed greatly concerning the behavior of abamectin residues in squash fruits (peel and unwashed fruits). Disappearance of abamectin residues in peel and unwashed whole fruits were obvious and sharp during the first 3 days reaching $75.51 \%$ and $81.89 \%$ loss, respectively. In squash peel abamectin was not detected on the day 9 after spraying and after 6 days in case of pulp, washed and unwashed fruits.

Concerning the effect of peeling and washing with tap water as a home processing on the reduction of abamectin residues in squash fruits, it is obvious to note that the removal percentages due to peeling were $100,89.85,63.16$ and $51.39 \%$ after $2 \mathrm{hrs}, 1,3$, and 6 days of spring, also the migration percentages of abamectin residues in relation to the initial deposits on squash peel were $0.00,7.14,14.29$ and $3.57 \%$, while in case of washing, data clearly indicated that the washing was effected on the residues of abamectin in squash fruits and the removal percentages ranged from 5.13 to $14.74 \%$.

The calculated half - life $\left(\mathrm{T}_{1 / 2}\right)$ value of cyflufenamid and abamectin on squash field were $0.18,0.21,0.37$ and 0.65 days for abamectin in squash peel, soil, unwashed fruits and leaves, respectively. While the corresponding values in case of cyflufenamid were $0.58,0.42,0.43$ and 2.61 days.
Based on the figures of maximum residues levels of the two tested pesticides $(0.05$ and $0.04 \mathrm{mg} / \mathrm{kg}$ for cyflufenamid and abamectin) presented in EU Pesticides database - European Commission, the corresponding contaminated squash pulp could be used safely after $2 \mathrm{hrs}$ and 6 days from the onset of pesticidal application, while in case of squash fruit (washed or unwashed) could be used safely for human consumption after 6 days. This phenomenon took place with the two tested pesticides.

Based on the results obtained in this study the following concluding points were reached:

1-It is obvious that there was a positive correlation between the uptake of the used two pesticides on the recipient surface of squash leaves, peel, pulp, unwashed fruits, washed fruits and soil under the treated plants and their used concentrations.

2-The initial amounts of each pesticide in leaves were much higher than those in squash fruits, such differences may be due to the differences in the area, morphology and chemistry of the recipient two surfaces. Many investigators recorded that lower content of insecticide residues were determined on fruits compared with leaves on several vegetable and field crops (Shalaby, 1998; Soliman, 1998; Ali, et al., 2016 and Ramadan et al., 2016).

3-Loss percentages in residues were higher in squash fruits than leaves; this may be due to increase 
growth rate of fruit which dilute the residue uptake in fruits and differences in metabolism since the role of natural degradation in both targets was similar. The figures of the rate of the two tested pesticides degradation as well as the half - life support this phenomenon, the figures of the rate of degradation in case of fruits are higher than those of leaves, and where as the inverse case could be observed with the figures of half - lives. (Rafa, 1998; Soliman, 1998; shalaby, 2012; Romeh and Hendawi, 2014; sleem 2015; Ali, et al., 2016 and Ramadan et al., 2016)

4-The residues amounts of the two tested pesticides were more greatly detected in peel higher than that the pulp. Such differences may be due to the affinity of the two pesticides to distributed and concentrated in squash peel as well as the physicochemical properties of the two tested pesticides such as the polarity and water solubility and special groups helping the residues to pass through the peel.

5-Data show that washing and peeling of squash fruits resulted in removing reasonable amounts of residues especially with the first three samples. This could be elucidated based on the increased rate of permeability with time elapsed. Several investigators pointed out that washing and peeling process resulted in removing magnitude amounts of different pesticides present on the surface of many vegetables, fruits and field crops. (Shokr, 1997, Shalaby, 1998; Radwanet al., 2005; Romeh and Hendawi, 2014; Shiboobet al., 2014 and sleem 2015)

\section{References}

AL-Eed, A.M. (2006). Determination of pirimiphosmethyl and chlorpyrifos-ethyl residues on tomato and pepperfruits grown in greenhouse. J. Appl. Sci., 6 (4):979-982.

Ali, A.A.I.; M.B.A. Ashour; M.R.A. Tohamy and Didair A. Ragheb (2016). Azoxystrobin residues on tomato leaves and fruits. Zagazig J. Agric. Res., 42 (6): 1547 - 1553.

Gonzalez, M.; K.S.B. Mig-Ioranza; J. E. Aizpum and V. J. Moreno (2003). Organochlorine pesticide residues in leek (Allium porum) crops grown on untreated soils from an agricultural environment. J. Agric. Food Chem., 51: 50245029.

Haramoto, M.; H. Yamanaka; H. Hosokawa; H. Sano; S. Sano and H. Otani (2006). Control efficacy of cyflufenamid in the field and its fungicidal properties. J. Pestic. Sci., 31(2), 116122.

Hirahara, Y.; M. Kimura; T. Inoue and M. Ota (2005).Validation of Multiresidue Screening Methods for the Determination of 186 Pesticides in 11 Agricultural Products Using Gas
Chromatography (GC). J. health science 51(5):617-627 .

Lehotay, S.J.; K.A. Son; H. Kwon; U. Koesukwiwat; W. Fu; K. Mastovska; E. Hoh and N. Leepipatpiboon (2010). Comparison of QuEChERS sample preparation methods for the analysis of pesticide residues in fruits and vegetables. J Chromatogr A., 16: 2548-60.

MacBean, C. (2012). The pesticide Manual version 5.2, fifteenth Ed. abamectin (1).

Radwan, M.A.; M.M. Abu-Elamayem; M.H. Shiboob and A. Abdel-Aal (2005). Residual behaviour of profenofos on some field-grown vegetables and its removal using various washing solutions and household processing. Food and Chemical Toxicology 43: 553-557.

Rafa, A.E. (1998). Determination of certain chlorinated and organophosphorus pesticide residues in vegetable and fruits. Ph. D. Thesis. Fac. Of Agric. Moshtohor, Zagazig Univ.

Ramadan, M.M.; M.A. El-Tantawy; M.B.A. Ashour and R.M. Sherif (2016). Pyridalyl insecticide residues in tomato plants. Zagazig $\mathrm{J}$. Agric. Res., 43 (1): 245 - 250.

Romeh, A.A. and M.Y. Hendawi (2014). Dissipation of fenpropathrin residues in squash fruits intercropped with garden rocket. Afr. J. Agric. Res., 9 (3): 307-309

Saitta, M.; G. Di-Bella; F. Salvo; S. Lo-Curto and G. Dugo (2000). Organochlorine pesticide residues in Italian citrus essential oils. J. Agric. Food Chem., 48: 797-801.

shalaby, A.A. (2012). Distribution of some pesticide residues in environment. Ph. D. Thesis. Fac. Of Agric., Zagazig Univ.

shalaby, A.A.; K.A. Gouhar; M.M.I Aamir and W.T.G Ghatwary (1998). Effect of spraying equipments on the residues of some insecticides and their efficiency against Aphis craccivora (Koch.) and Empoascadecipiens (Paoli.) attacking cowpea plants. Egypt. J. Appl. Sci; 13(12) 638653.

Shiboob, M. H.; M. H. Madkour and A. A. Zaitoun(2014). Effect of washing and household processing on removal performance of some organophosphorus insecticides. J. of Food, Agric. \& Envir.12 (2 ): 1255 - 1259.

Shokr, A.A.S. (1997). Environmental pollution by pesticide residues. Ph. D. Thesis. Fac. Of Agric. Kafr El-Shekh Tanta Univ.

Sleem, F.M.A. (2015). Persistence of some pesticides in and on some crops. Ph. D. Thesis. Fac. Of Agric., Benha Univ.

Soliman, M.H.A. (1998). Studies on certain pests infesting some cucurbitaceous plants. M. Sc. Thesis. Fac. Of Agric., Zagazig Univ. 


\section{سلوك متبقيات مبيدى الابامكتين وسيفليفيناميد فى نباتات الكوسة \\ على عطا على شلبى \\ قسم وقاية النبات - كلية الزراعة - جامعة الزقازيق - مصر}

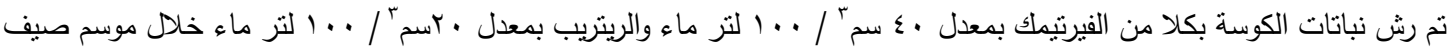

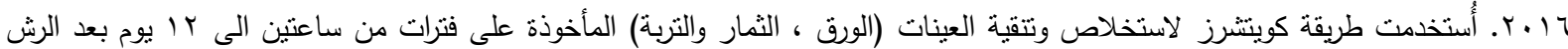

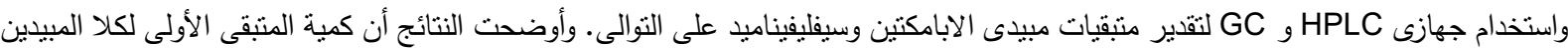

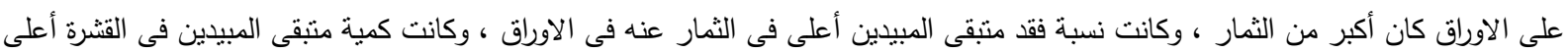
من اللب ، وكان الغسيل بالماء والتقتير لهم دور كبير فى التخلص من متبقى المبيدين وخاصة فى الثنلاث عبنات الاولى. وجد أن معدل تحطم مبيد الابامكتين كان أكبر من معدل تحطم مبيد السيفليفيناميد ويمكن إستهلاك الثمار بآمان بعد 1 أيام من المعاملة. 